\title{
Developing Eco-Theological Concepts in Indonesia
}

\author{
Ferry Simanjuntak, Christopher Alexander, Hana Venturini, Stivani Lumbantoruan, Jeremy Mulyadi \\ Kharisma Theological Seminary Bandung, Indonesia \\ Correspondence Author*
}

\begin{abstract}
Humans are one of the biggest causes of environmental damage. Of course, this is contrary to what God wants as it is written in the Bible, that humans should live in harmony with nature, by protecting and managing it. For this reason, the authors raise the topic of "Developing Eco-Theological Concepts in Indonesia" to answer the need for environmental problems in Indonesia so that they can be resolved properly and to fulfill the will of God at the same time. The authors used a research method in the form of library research by using several existing literature sources to support the authors' thoughts. The conclusion of this study is that there are three groups of people that can help develop the concept of eco-theology in Indonesia, namely (1) the general public, by returning to the Theocentric concept of the Bible; (2) educational institutions, by incorporating an ecopedagogy-based curriculum; (3) the Indonesian government, by developing and promoting research from previous researchers regarding the development of the ecogreen concept in Indonesia.
\end{abstract}

Keywords: ecology; eco-theology; ecopedagogy; ecogreen

\section{INTRODUCTION}

$\mathrm{E}$ nvironmental issues are a major topic to discuss by countries around the world, including Indonesia. The exploitation of nature is one of those things that is concerned by the Indonesian Government. The exploitation of nature is the act of humans in exploiting natural resources and the environment without limits for their own benefit. ${ }^{1}$ Forestandland fires are a form of natural exploitation that causes natural disasters. Natural disasters can occur followed by climate change. Based on the National Board for Disaster Management in Indonesia, every year, there were natural disasters including floods and landslides. In 2016, there were 2,306 natural disasters, and 2,866 incidents in 2017. On the other hand, there were 3,397 incidents in 2018, and 3,814 incidents in 2019. The number of the incidents increased in those two years. But in 2020, there were 2,952 incidents, which means the number of the incidents was decreased in that year. The similarity of these natural disasters that occur from 2016-2020 is that floods and landslides always dominate among the other natural disasters, and one of the causes of floods and landslides is forestandland fires.

Based on the Ministry of Environment and Forestry of the Republic of Indonesia, there was a decrease in the number of forestandland fires in every province of Indonesia, starting from 2016-2020. In 2016, the area of forestandland fires was $438,363.19$ hectares and there were $165,483.92$ hectares in

${ }^{1}$ KalisStevanus, "Pelestarianalamsebagaiperwujudanmandatpembangunan: suatukajianetis-teologis," Jurnal Teologidan Pendidikan Agama Kristen Vol 5, No. 20 (2019): 95.
2017. During those two years, there was a twofold decrease in the number of forest and land fires in Indonesia. But during the next two years, there was a threefold increase, proven with there were 529,266.64 hectares in 2018, and there were $1,649,258.00$ hectares in 2019. While in 2020,there were 296,942.00 hectares. ${ }^{2}$ Even though the Indonesian Government has issued various regulations on forest protection, the forestandland fires that occurred in Indonesia still can't be overcome, this is due to the lack of law enforcement against forest burning perpetrators. Agustiar et al. said that 'the forestandland fires that occur are not natural disasters, but are caused by humans who are greedy for property'?

As stated by Siregar and $\mathrm{Zul}$, Indonesia is one of the countries with very concerning environmental problems, where there are many cases of environmental pollution and exploitation of nature such as illegal logging, which causes serious damage to the environment. The problem is how the regulation of environmental crimes in Indonesia can be enforced. ${ }^{4}$

Environmental degradation is getting worse when humans with the help of science and technology make drastic changes to the environment which are called development. Humans are one of the biggest causes of environmental damage. ${ }^{5}$ This is contrary to what the Bible says about how God wants mankind to live in harmony with nature, by protecting and managing nature. For this reason, the authors feel the need to raise the topic of "Developing Eco-Theological Concepts in Indonesia" in order to answer the need for environmental problems in Indonesia so they can be resolved properly and to fulfill God's will at the same time.

\section{METHODOLOGY}

This research method is a literature study method, which is known as Library Research. Literature study is a study that is used to collect information and data through various kinds of materials in the library such as documents, books, magazines,

\footnotetext{
2 'Indonesian ForestandLand Fires Monitoring System, 'RekapitulasiLuas Kebakaran Hutandan Lahan (Ha) Per Provinsi Di Indonesia Tahun 20162021', (2021).

${ }^{3}$ Ahsanul Buduri Agustiardkk., "KEBAKARAN HUTAN DAN LAHAN PERSPEKTIF ETIKA LINGKUNGAN," JurnalStudi Islam 20, no. 2 (Desember 2019): 124.

${ }^{4} J a n u a r i$ Siregardan MuazZul, "PENEGAKAN HUKUM DALAM TINDAK PIDANA LINGKUNGAN HIDUP DI INDONESIA," Mercatoria 8, no. 2 (2015): 119.

${ }^{5}$ Marianus Patora, "Peranan Kekristenan dalam Menghadapi Masalah Ekologi," JURNAL TERUNA BHAKTI 1, no. 2 (19 Maret 2019): 117-27, https://doi.org/10.47131/jtb.v1i2.19.
} 
historical stories, etc. Literature study is also studying various books and similar previous research results that are useful for obtaining a theoretical basis on the problem to be studied. Literature study also means data collection techniques by reviewing books, literature, notes and various reports related to the problem to be solved. ${ }^{6}$ First of all, the author analyzed the situation of the environment in Indonesia by looking for reliable data from the government sector. Then the author would propose several suggestions regarding steps to deal with environmental problems in Indonesia by developing the concept of eco-theology in Indonesia. The authors would express the authors' thoughts assisted by research from previous researchers which support the topic that the authors raise.

\section{RESULTS AND DISCUSSION}

\section{Ecology versus Eco-theology}

According to Ernst Haeckel, ecology is a comprehensive science that studies the relationship between organisms and their environment. Burdon-Sanderson explained that ecology is the study of external relationships between plants and animals, as well as their existence in the past and present. These external relations are used to distinguish between physiology (internal relations) and morphology (structure). Based on the definitions above, it can be concluded that ecology is the study of the inter-relationship between organisms or between organisms and their environment. There are five scopes of ecology: individual, population, community, ecosystem, and biosphere. Individual is the smallest unit of an organism, then the biosphere is the largest unit of an organism. ${ }^{7}$

Eco-theology is a theological concept that includes a christian theological approach to nature. Eco-theology means the study of the earth as a human's habitation from God's point of view. Eco-theology emphasizes the maintenance of all of God's creation on earth, such as plants, animals and other natural resources. In addition, eco-theology also pays more attention to the relationship between humans and nature as a mandate that God has given and maintains the created nature (Genesis $1: 28-30)^{8}$

\section{Anthropocentrism Versus Bible Perspective About Ecology}

Anthropocentrism is a theory of environmental ethics. It views humans as the center of the universe system. This perspective is followed by the idea that the world was created only for human benefit. Anthropocentrism's perspective is accused as

${ }^{6}$ Abdi Mirzaqon T., "StudiKepustakaanMengenaiLandasanTeori Dan PraktikKonseling Expressive Writing: Library Research Of The Basic Theory And Practice Of Expressive Writing Counseling," FakultasIlmuPendidikan, UniversitasNegeri Surabaya, t.t., 1-8.

${ }^{7}$ Rahayu Effendi, Hana Salsabila, dan Abdul Malik, "PEMAHAMAN TENTANG LINGKUNGAN BERKELANJUTAN," MODUL 18, no. 2 (22 November 2018): 75-76, https://doi.org/10.14710/mdl.18.2.2018.75-82.

${ }^{8}$ SabdaBudiman, Kiki Rutmana, dan Kristian KariphiTakameha, "PARADIGMA BEREKOTEOLOGI DAN PERAN ORANG PERCAYA TERHADAP ALAM CIPTAAN: KAJIAN EKOTEOLOGI," 2021, 21-31. the main cause of environmental damage or crisis because this perspective makes humans have a mindset to supply nature to meet the needs of life without protecting human nature. According to Franz Magnis Suseno, anthropocentrism's perspective is the same as the capitalist economic perspective. A capitalist economy focuses on profit-seeking by exploiting nature without considering the consequences and risks of exploiting nature. There are several triggers for the emergence of this anthropocentric view, first, there is a mistake in the interpretation of the book of Genesis. Second, the existence of western philosophy (Aristotelian culture) and the entire Liberal tradition, one of which is modern science. The emergence of two views on the creation story between the book of Genesis and the thoughts of philosophers affects the perspective and behavior of humans towards nature and the environment. ${ }^{9}$

Genesis 1:26-28, it is stated that God created man in the image and likeness of God, and man is His highest creation. Humans have a mandate to cultivate and maintain nature. God gave the universe and its contents (including animals and plants) to be controlled and conquered. This teaching has been misinterpreted that humans are given the right by God Himself to control and exploit the universe and everything in it for the sake of their life. The word "conquer the whole earth" is not talking about govern, where humans control nature, but it is talking about responsibility, full responsibility and obligation to protect nature ${ }^{10}$ Also, according to Robert, this command is understood as ratification of the status of humans as rulers of the world which is often associated with the idea that humans are representatives of God in the world. According to Drummond, this misinterpretation may occur because it is driven by the success of science and technological innovation and human power. Genesis 2:9 also has been misinterpreted. Before eating forbidden fruit, humans automatically obeyed God's will. However, after eating it, humans' eyes were opened and they knew what was morally good and what was morally bad. They no longer obeyed God's commands automatically, but decided for themselves what was good to do and what was bad to avoid. According to Keraf, in relation to the universe, humans began to know which creatures are good that can be nurtured and which creatures are not good that need to be eradicated. ${ }^{11}$

\section{Developing Eco-Theological Concepts}

By seeing the importance of a correct understanding of the biblical concepts of ecology, it is necessary to develop the

${ }^{9}$ Yusup Rogo Yuono, "ETIKA LINGKUNGAN: MELAWAN ETIKA LINGKUNGAN ANTROPOSENTRIS MELALUI INTERPRETASI TEOLOGI PENCIPTAAN YANG TEPAT SEBAGAI LANDASAN BAGI PENGELOLAAN-PELESTARIAN LINGKUNGAN," FIDEI: Jurnal Teologi Sistematika dan Praktika 2, no. 1 (18 Juni 2019): 191, https://doi.org/10.34081/fidei.v2i1.40.

${ }^{10}$ Feldy Lolangion, Marselino Cristian Runturambi, dan Jefry Kawuwung, "Menelaah Antroposentris Dalam Menyikapi Krisis Lingkungan Dari Perspektif Teologi Penciptaan," Титои Tои 8, no. 1 (31 Januari 2021): 7, https://doi.org/10.51667/tt.v8i1.469.

${ }^{11}$ Yuono, "ETIKA LINGKUNGAN.", 193. 
concept of eco-theology in Indonesia. The authors conclude that there are three groups of people targeted by the authors which can help develop the concept of eco-theology in Indonesia, which are society in general, educational institutions, and the Indonesian government.

\section{A. Society in general: 'Back to Bible'}

Talking about building environmental theology, it must be in accordance with the concept of Theocentric view (anthropocentric is human-centered, Theocentric is Godcentered). God should be the center because the efforts to manage and preserve nature can't be separated from God who is the Creator itself.

In Genesis chapters 1 and 2, implies that since the creation, God has shown that man is part of His natural environment. ${ }^{12}$ Genesis 1:27 says that man was created in His image. According to Robert P. Borong, Genesis 1:26-28 understands that the mandate of natural control is related to understanding the nature of human creation as the image of $\operatorname{God}^{13}$, it means that humans are representatives and sign of the presence of God's government over all creation. ${ }^{14}$ The word "power" and "conquer" (Gen 1:28) in Hebrew namely radah and kabash which literally means trample and squeeze, but if interpreted, these words emphasize the human function of upholding and exercising God's right to the world. James Nash, as quoted by Robert Borong, said that the use of these words is to convince humans that they will face the challenges of nature in order to maintain their life. Therefore, the responsibility of humans is not to exploit nature to fulfill their personal interest. The power that God has given to humans doesn't mean that humans are superior beings over others. The power that God has given to humans also means that humans are given the mandate to manage, protect and maintain nature in such a way so humans and other creatures can live together in this world. ${ }^{15}$

\section{B. Educational Institutions: Ecopedagogy-Based Curriculum}

Etymologically, the term ecopedagogy comes from two words, namely ecology (which means the study of reciprocal relationships between living things and their environment), and pedagogy (which means the science of education, both theoretically and practically based on philosophical values). As Khan said, ecopedagogy is an academic movement that aims to make students aware so that they have understanding, awareness and life skills that are in line with the interests of natural conservation. ${ }^{16}$

\footnotetext{
${ }^{12}$ Patora, "Peranan Kekristenandalam Menghadapi Masalah Ekologi.", 125

${ }^{13}$ Frets Keriapy, "Ekologi Dalam Perspektif Iman Kristen (Mengungkapkan Masalah Ekologi Indonesia)," preprint (Open Science Framework, 4 Desember 2019), https://doi.org/10.31219/osf.io/7r65d.

${ }^{14}$ Yuono, "ETIKA LINGKUNGAN.", 200.

${ }^{15}$ Keriapy, "Ekologi Dalam PerspektifIman Kristen (Mengungkapkan Masalah Ekologi Indonesia)."

${ }^{16}$ Hana Yunansah dan Yusuf Tri Herlambang, "PENDIDIKAN BERBASIS EKOPEDAGOGIK DALAM MENUMBUHKAN KESADARAN EKOLOGIS DAN MENGEMBANGKAN KARAKTER SISWA SEKOLAH
}

According to Gule $^{17}$, there are at least five aims of environmental education (ecopedagogy) formulated by the international community, namely (1) the field of knowledge: environmental education aims to help individuals to gain experience and knowledge in managing and protecting the environment; (2) the field of awareness: environmental education aims to increase awareness and sensitivity of each individual to the problems that are happening related to the environment; (3) the field of behavior: environmental education aims to help each individual to have a sense of concern for the environment and encourage individuals to actively participate in environmental protection and improvement; (4) the field of skills: environmental education aims to equip every individual to have skills in managing, maintaining and even anticipating/preventing environmental damage; and (5) the field of participation: environmental education aims to provide space and opportunity for every individual to take an active part in creating a sustainable living environment. Yunansah and Herlambang concluded that ecological awareness needs to be the most important part in the purpose of education, where in fact this ecological education aims to hone one's sensibility to ecological problems and raise awareness of how valuable the nature is for human life, which will then make a person be aware of how important it is to protect and preserve the environment. ${ }^{18}$

To develop the concept of eco-theology, especially in the field of education, we need to focus on transformative education, where the goal is to change paradigms and ways of thinking in acting and relating to nature. ${ }^{19}$ Actually, ecopedagogy views environmental education with a holistic perspective as a whole human. The important point here is sustainable and social development transformation. Due to increasing consumerism, people tend to spend and consume more regardless of whether they really need it or not. Therefore, humans must limit their consumptive behavior for sustainable development. ${ }^{20}$ Based on the explanation above, the authors consider it necessary to incorporate the concept of eco-theology into educational institutions through an ecopedagogical approach that is incorporated into the school curriculum, starting from elementary school to university.

\section{Indonesian Government: Ecogreen}

DASAR," EduHumaniora | Jurnal Pendidikan Dasar Kampus Cibiru 9, no. 1 (11 April 2017): 28-29, https://doi.org/10.17509/eh.v9i1.6153.

${ }^{17}$ Yosefo Gule, "Konsep Eduecologi dalam Pendidikan Agama Kristen Konteks Sekolah," FIDEI: Jurnal Teologi Sistematika dan Praktika 3, no. 2 (2020): 189-190, https://doi.org/10.34081/fidei.v3i2.183.

${ }^{18}$ Yunansahdan Herlambang, "PENDIDIKAN BERBASIS EKOPEDAGOGIK DALAM MENUMBUHKAN KESADARAN EKOLOGIS DAN MENGEMBANGKAN KARAKTER SISWA SEKOLAH DASAR.", 28.

${ }^{19}$ Gule, "Konsep Eduecologidalam Pendidikan Agama Kristen KonteksSekolah.”, 189.

${ }^{20}$ Emel Okur-Berberoglu, "The Effect of Ecopodagogy-Based Environmental Education on Environmental Attitude of In-Service Teachers," International Electronic Journal of Environmental Education 5, no. 2 (21 September 2015): 101, https://doi.org/10.18497/iejee-green.09988. 
Regarding the ecogreen concepts in Indonesia, there have been many researchers from Indonesia contributing their thoughts on how they can help the Indonesian government to advance the ecogreen concepts in Indonesia. For this reason, on this occasion, the authors will help the previous researchers to bring these concepts back to the surface, so that the Indonesian government can further realize and promote ecogreen concepts that have been outlined by the previous Indonesian researchers. The two of them are:

First, a research conducted by Andini et al. ${ }^{21}$, where in their journal entitled "Implementation of green human resources management through pro-environmental behavior in Alpina Hotel \& Spa Chamonix France", they contributed their thoughts on how to implement the concept of green human resources management in a hotel. There are three aspects related to the implementation of the concept of green human resources management, namely: (1) green competencies, that all workers must be educated to have knowledge and awareness of environmental problems; (2) green attitude, that all workers start looking for and doing eco-friendly activities; (3) green behavior, that all workers are consciously having pro-environmental behavior. By applying the concepts of green human resources management, it is expected to reduce the negative environmental impact, so that the environment can be maintained properly. This concept can clearly be adopted by the Indonesian government, especially the Ministry of Manpower and Transmigration, to be able to develop the concept of eco-green in Indonesia by creating green human resources.

Second, a research conducted by Soegiantoro et al. ${ }^{22}$, where in their research entitled "Home-Made Eco Green Biodiesel From Chicken Fat (CIAT) and Waste Cooking Oil (PAIL)", they contributed their thoughts on how they could help the Indonesian government to produce biodiesel effectively and efficiently. According to the economic analysis, they conclude that the production costs of CIAT and PAIL biodiesel, which are produced by using home-made biodiesel reactors, were cheaper than the government biodiesel fuel selling price. This research may be considered as an additional alternative for the government, to produce biodiesel at home, in order to develop the concept of eco-green in Indonesia.

\section{CONCLUSION}

Seeing the rampant environmental damage that has occurred in Indonesia, the authors conclude that every Indonesian citizen must return to what was originally set by God, where humans should live in harmony with nature, by protecting and managing nature properly.

\footnotetext{
${ }^{21}$ Putu Kania Andini, Ni Nyoman Sri Astuti, dan I Ketut Budarma, "Implementation of Green Human Resources Management through ProEnvironmental Behavior in Alpina Hotel \& Spa Chamonix France," International Journal of Green Tourism Research and Applications 2, no. 2 (2020): 63-71, http://dx.doi.org/10.31940/ijogtra.v2i2.2069.

${ }^{22}$ Gregory Hope Soegiantoro dkk., "Home-Made Eco Green Biodiesel From Chicken Fat (CIAT) and Waste Cooking Oil (PAIL)," Energy Procedia 158 (t.t.): 1105-9, https://doi.org/10.1016/j.egypro.2019.01.267.
}

The conclusion of this study is that there are three groups of people that can help develop the concept of eco-theology in Indonesia, namely (1) the general public, by returning to the Theocentric concept of the Bible; (2) educational institutions, by incorporating an ecopedagogy-based curriculum; (3) the Indonesian government, by developing and promoting research from previous researchers regarding the development of the ecogreen concept in Indonesia.

\section{REFERENCE}

[1] Agustiar, AhsanulBuduri, Mustajib, Fadlilatul Amin, dan Ahmad FauzanHidayatullah. "KEBAKARAN HUTAN DAN LAHAN PERSPEKTIF ETIKA LINGKUNGAN.” JurnalStudi Islam 20, no. 2 (Desember 2019): 124-32.

[2] Andini, Putu Kania, Ni Nyoman Sri Astuti, dan I Ketut Budarma. "Implementation of Green Human Resources Management through Pro-Environmental Behavior in Alpina Hotel \& Spa Chamonix France." International Journal of Green Tourism Research and $\begin{array}{lllll}\text { Applications } 2, & \text { no. } & 2 & \text { (2020): }\end{array}$ http://dx.doi.org/10.31940/ijogtra.v2i2.2069.

[3] Budiman, Sabda, Kiki Rutmana, dan Kristian KariphiTakameha. "PARADIGMA BEREKOTEOLOGI DAN PERAN ORANG PERCAYA TERHADAP ALAM CIPTAAN: KAJIAN EKOTEOLOGI," 2021, 21-31.

[4] Effendi, Rahayu, Hana Salsabila, dan Abdul Malik. "PEMAHAMAN TENTANG LINGKUNGAN BERKELANJUTAN." MODUL 18, no. $2 \quad$ (22 November 2018): https://doi.org/10.14710/mdl.18.2.2018.75-82.

[5] Gule, Yosefo. "Konsep Eduecologi dalam Pendidikan Agama Kristen Konteks Sekolah.” FIDEI: Jurnal Teologi Sistematika dan Praktika 3, no. 2 (2020): 181-201. https://doi.org/10.34081/fidei.v3i2.183.

[6] Keriapy, Frets. "Ekologi Dalam Perspektif Iman Kristen (Mengungkapkan Masalah Ekologi Indonesia)." Preprint. Open Science Framework, 4 Desember 2019. https://doi.org/10.31219/osf.io/7r65d.

[7] Lolangion, Feldy, Marselino Cristian Runturambi, dan Jefry Kawuwung. "Menelaah Antroposentris Dalam Menyikapi Krisis Lingkungan Dari Perspektif Teologi Penciptaan.” Tumou Tou 8, no. 1 (31 Januari 2021): 1-9. https://doi.org/10.51667/tt.v8i1.469.

[8] Mirzaqon T., Abdi. "StudiKepustakaanMengenaiLandasanTeori Dan PraktikKonseling Expressive Writing: Library Research Of The Basic Theory And Practice Of Expressive Writing Counseling." FakultasIlmuPendidikan, Universitas Negeri Surabaya, t.t., 1-8.

[9] NN. 'Indonesian Forest and Land Fires Monitoring System, 'RekapitulasiLuasKebakaranHutandanLahan (Ha) Per Provinsi Di Indonesia Tahun 2016-2021', (2021).

[10] Okur-Berberoglu, Emel. "The Effect of Ecopodagogy-Based Environmental Education on Environmental Attitude of In-Service Teachers." International Electronic Journal of Environmental Education 5, no. 2 (21 September 2015): 86-110. https://doi.org/10.18497/iejee-green.09988.

[11] Patora, Marianus. "Peranan Kekristenan dalam Menghadapi Masalah Ekologi." JURNAL TERUNA BHAKTI 1, no. 2 (19 Maret 2019): 11727. https://doi.org/10.47131/jtb.v1i2.19.

[12] Siregar, Januari, danMuazZul. "PENEGAKAN HUKUM DALAM TINDAK PIDANA LINGKUNGAN HIDUP DI INDONESIA." Mercatoria 8, no. 2 (2015): 107-31.

[13] Soegiantoro, Gregory Hope, Jesslynn Chang, Puput Rahmawati, Maria Faeka Christiani, dan Zahrul Mufrodi. "Home-Made Eco Green Biodiesel From Chicken Fat (CIAT) and Waste Cooking Oil (PAIL)." Energy Procedia $158 \quad$ (t.t.): 1105-9. https://doi.org/10.1016/j.egypro.2019.01.267.

[14] Stevanus, Kalis. "Pelestarian alam sebagai perwujudan mandat pembangunan: suatu kajian etis-teologis." Preprint. Open Science Framework, 18 Oktober 2020. https://doi.org/10.31219/osf.io/s79e2.

[15] Yunansah, Hana, dan Yusuf Tri Herlambang. "PENDIDIKAN BERBASIS EKOPEDAGOGIK DALAM MENUMBUHKAN KESADARAN EKOLOGIS DAN MENGEMBANGKAN 
International Journal of Research and Innovation in Social Science (IJRISS) |Volume V, Issue VI, June 2021|ISSN 2454-6186

KARAKTER SISWA SEKOLAH DASAR.” EduHumaniora | Jurnal Pendidikan Dasar Kampus Cibiru 9, no. 1 (11 April 2017): 27-34. https://doi.org/10.17509/eh.v9i1.6153.

[16] Yuono, Yusup Rogo. "ETIKA LINGKUNGAN: MELAWAN ETIKA LINGKUNGAN ANTROPOSENTRIS MELALUI
INTERPRETASI TEOLOGI PENCIPTAAN YANG TEPAT SEBAGAI LANDASAN BAGI PENGELOLAAN-PELESTARIAN LINGKUNGAN." FIDEI: Jurnal Teologi Sistematika dan Praktika 2, no. 1 (18 Juni 2019): 183-203. https://doi.org/10.34081/fidei.v2i1.40. 